\title{
NRXN2 wt Allele
}

National Cancer Institute

\section{Source}

National Cancer Institute. NRXN2 wt Allele. NCI Thesaurus. Code C124913.

Human NRXN2 wild-type allele is located in the vicinity of $11 q 13$ and is approximately 117

$\mathrm{kb}$ in length. This allele, which encodes neurexin-2 protein and neurixin-2-beta protein,

may be involved in neuronal cell adhesion. 